\title{
Historical prerequisites for the formation of quality criteria in the development of high- speed rail lines
}

\author{
Vladimir Okrepilov ${ }^{1}$, Tatiana Lebedevaa ${ }^{2,}$, Svetlana Kuzmina ${ }^{2}$, and Andrey Yakovlev $^{2}$ \\ ${ }^{1}$ Institute for Problems of Regional Economics RAS, St. Petersburg, Russian Federation \\ ${ }^{2}$ Peter the Great St. Petersburg Polytechnic University, St. Petersburg, Russian Federation
}

\begin{abstract}
An increase in the speed of various flows, both information and transport ones, including in railway transport, requires compliance with increasingly large number of criteria conditions. Such criteria are safety, economic efficiency, environmental friendliness, comfort and ergonomics for both an individual passenger and passenger traffic. Over more than half a century of history, high-speed railways have become a continuously developing innovative industry that ensures compliance with all the above conditions and provides a further large-scale field of scientific activity. The pace of their construction is increasing, despite the reduction in the total length of the railway network in the world and digital economy.
\end{abstract}

\section{Introduction}

In different countries of the world, there are different requirements for high-speed rail lines (HSR), express rail lines (ER), which also provide their own specific sets of quality criteria related, for example, to analysis of passenger traffic [1] or the total length of a railway network [2]. The European Union is governed by Directive 96/48/EC App. 1 [3], which states that "high-speed rail lines are a set of three elements: infrastructure, i.e. features of railway lines that allow developing high speeds, the minimum developed speed of $250 \mathrm{~km} / \mathrm{h}$, and the operating conditions of the line, i.e. rolling stock should be technically designed to move along such lines" [4]. The International Union of Railways has defined a much wider set of requirements, for example, one of the documents states that "high-speed railways are a set of unique criteria. Today, there is no single international standard for high-speed lines" [5].

From the first days of the emergence of rail transport, speed was one of the most important factors. The desire to achieve high speeds was dictated by a number of criteria, such as capacity, density of the traffic, competition with other modes of transport, information flow speed, discreteness of flow, expansion of trade routes [6].

Due to the accelerating pace of scientific and technological progress, mankind is trying to bring the speed of material flow closer to the speed of information flow. For example, with the emergence of global networks and the occurrence of an increasing number of

\footnotetext{
*Corresponding author: foxfree@mail.ru
} 
online stores, the buyer forces the seller to deliver his material product as quickly as possible. Therefore, the seller who provides not only a high-quality product but also highquality delivery, which includes not only a defect-free look (not damaged during transportation) but also the delivery speed [7], will be most preferable.

Table 1. Research in the field of high-speed rails.

\begin{tabular}{|c|c|}
\hline $\begin{array}{l}\text { Abelson P. } \\
\text { and Hensh } \\
\text { er P. } \\
2001\end{array}$ & $\begin{array}{l}\text { "Induced travel and user benefis: clarifying definitions and measurement for urban } \\
\text { road infrastructure," in Hensher, D. and Button, K. (eds.): Handbook of transport } \\
\text { systems and traffic control, Handbooks in Transport 3. Elsevier, Pergamon. }\end{array}$ \\
\hline $\begin{array}{l}\text { Adler N., } \\
\text { Nash C. a } \\
\text { nd Pels E. } \\
\quad 2007\end{array}$ & $\begin{array}{l}\text { "Infrastructure Pricing: The Case of Airline and High Speed Rail Competition," } \\
\text { Paper presented at the 11th World Conference on Transport Research, Berkeley. }\end{array}$ \\
\hline $\begin{array}{l}\text { Atkins. } \\
2004\end{array}$ & $\begin{array}{l}\text { High speed line study. Department of Environment, Transport and the } \\
\text { Regions. London. }\end{array}$ \\
\hline $\begin{array}{l}\text { Banister D } \\
\text {. and } \\
\text { Givoni M. } \\
2006\end{array}$ & "Airline and railway integration," Transport Policy, 13(4): 386-397. \\
\hline $\begin{array}{l}\text { Becker, G. } \\
\text { S. } 1983\end{array}$ & $\begin{array}{l}\text { "A theory of competition among pressure groups for political influence," The } \\
\text { Quarterly Journal of Economics } 98 \text { (3): } 371-400 \text {.CrossRef }\end{array}$ \\
\hline $\begin{array}{l}\text { Becker G. } \\
\text { S. } \\
2001\end{array}$ & $\begin{array}{l}\text { "A comment on the conference on cost-benefit analysis," } \\
\text { in Adler, M.D. and Posner, E.A. (eds) Cost-benefit analysis: Legal, economic and } \\
\text { philosophical perspectives, Chicago: The University of Chicago Press. }\end{array}$ \\
\hline $\begin{array}{c}\text { Blum U., } \\
\text { Haynes K. } \\
\text { E. and Kar } \\
\text { lsson C. } 1 \\
997\end{array}$ & $\begin{array}{c}\text { "Introduction to the special issue The regional and urban effects of high-speed } \\
\text { trains," The Annals of Regional Science, 31: 1-20.CrossRef }\end{array}$ \\
\hline $\begin{array}{l}\text { Bonnafous } \\
\text { A. } \\
1987 \\
\end{array}$ & "The Regional Impact of the TGV," Transportation 14: 127-137.CrossRef \\
\hline $\begin{array}{l}\text { Campos J. } \\
\text { and de } \\
\text { Rus G. } \\
2009 .\end{array}$ & $\begin{array}{c}\text { "Some stylized facts about high-speed rail: A review of HSR experiences around the } \\
\text { world," Transport Policy, 16(1): 19-28.CrossRef }\end{array}$ \\
\hline $\begin{array}{l}\text { CE Delft. } \\
2003 .\end{array}$ & $\begin{array}{l}\text { "To shift or not to shift, that's the question. The environmental performance of the } \\
\text { principal modes of freight and passenger transport in the policymaking } \\
\text { context." Delft. }\end{array}$ \\
\hline $\begin{array}{l}\text { de Rus G. } \\
2008\end{array}$ & $\begin{array}{c}\text { "The Economic effects of high-speed rail investment," OECD-ITF Transport } \\
\text { Research Centre. Discussion Paper, 2008-16. }\end{array}$ \\
\hline
\end{tabular}

\section{Methods}

In the paper, the authors analyze the requirements for high-speed rail lines, which are essentially the quality criteria for this type of transport.

Traditionally, system quality criteria include:

1. Suitability criterion.

2. Optimality criterion.

3. Superiority criterion.

The methodology for determining quality criteria in this case will be based on the calculation of particular and generalized indicators, taking into account the possibilities of their normalization. When assessing the quality of systems, it is advisable to distinguish 
several levels of quality, which are ranked in order of increasing complexity of the considered properties.

High-speed rail lines are a complex technical system that must be assessed from various positions in a comprehensive manner: management quality and quality of service.

Therefore, the traditional methodology should be supplemented taking into account the specific requirements for high-speed rail lines, including indicators and criteria for the effectiveness of systems. However, assessing the effectiveness of the high-speed rail is a question that requires a detailed and more thorough study, additional research. Thus, due to its vastness, it will not be presented in this paper.

\section{Quality criteria for high-speed rail lines can be divided into two blocks:}

Criteria that are associated with the consumer, for example, safety, comfort, ergonomics for an individual passenger.

Criteria that are associated with economic agents of the national economy as a whole, for example, economic efficiency, environmental friendliness, ergonomics for passenger traffic.

At the same time, it should be borne in mind that for a specific region or country, these quality criteria can be supplemented depending on the specifics of the territory, which will be presented below.

There is variety of methods to identify areas of quality in the road network.

From previous research (Persaud and Hauer, 1984, Persaud, 1986, 1988 and Hauer, 1997) it can be noted that methods relying on a simple ranking of crash counts leading to the attempted remediation of safety problems at relatively safe locations. Hauer and Persaud (1984) drew an analogy between the first stage of identification of black spots, and discussed how to measure the performances of various methods of identifying hotspot sites. On the basis of this study, Higle and Hecht (1989) conducted a simulation experiment to evaluate and compare techniques for the identification of hazardous locations in terms of crash rates. Maher and Mountain (1988) also use a simulation-based approach to compare methods, including ranking of sites on the basis of annual accident totals and potential accident reduction.

The studies on the rail network can be noted in the report that presented a risk-based model for identifying highway-railway grade crossing black spots in Canada (Saccomanno et al. 2003, 2004). This report consists of two prediction components: 1) collision frequency; 2) collision Consequence. Poisson and Negative Binomial (NB) frequency prediction expressions were developed for crossings. Typical absolute collision prediction models were developed by Coleman and Stewart (1976) and the U.S. Department of Transportation (USDOT) (1987). The USDOT model is generally recognized as being the industry standard for collision risk prediction at highway-rail grade crossings.

We will successively consider activities in the field of creating high-speed lines in Europe, the USA, China, Japan, and Russia.

The first "tests" of work in the field of high-speed rail lines in Europe were carried out by the Germans in 1899. The railway between Marienfelde and Zossen, $72 \mathrm{~km}$ long, was able to reach a traffic speed of $210.2 \mathrm{~km} / \mathrm{h}$ after four years of experiments, but it did not become regular. And the "Fliegender Hamburger" diesel fixed as regular between Hamburg and Berlin with a maximum speed of $160 \mathrm{~km} / \mathrm{h}$ in 1933 . When the Henschel-Wegmann steam train was introduced at its maximum speed of $160 \mathrm{~km} / \mathrm{h}$ in 1936 , the high-speed line began to spread throughout Germany, but World War II made some changes.

Since 1938, Italy has had its own high-speed line with their ETR 200 train, which also developed a speed of $160 \mathrm{~km} / \mathrm{h}$ and in the same year broke the record of that time with 203 $\mathrm{km} / \mathrm{h}$. And a little later, in the same year in the UK, the train with the "mallard" locomotive broke the record and reached $202.58 \mathrm{~km} / \mathrm{h}$. 
With the end of World War II, the race for speed continued. In the 1950s, the first rail transport speed records were set in excess of $300 \mathrm{~km} / \mathrm{h}$. In France, the CC 7107 trains and the BB 9001 prototype reached speeds of $320 \mathrm{~km} / \mathrm{h}$ and $331 \mathrm{~km} / \mathrm{h}$, respectively [8].

During the sixties, France, despite the fact that it had Aérotrain, which could reach 345 $\mathrm{km} / \mathrm{h}$, but only as a proof of concept, lagged behind Japan and Germany with their speeds of more than $200 \mathrm{~km} / \mathrm{h}$ against $160 \mathrm{~km} / \mathrm{h}$. Therefore, Edgard Pisani gave an explicit instruction to catch up with Germany and Japan in twelve months. This is how the Lignes à grande vitesse LGV (French high-speed railway network since 1981) emerged between Paris and Lyon, with a length of $2,800 \mathrm{~km}$, which reaches $270 \mathrm{~km} / \mathrm{h}$, but can go at a speed of $574 \mathrm{~km} / \mathrm{h}$ (2007 record).

Since 2000, active construction of high-speed lines is underway by several European countries, including several international ones: Italy - France - Switzerland - Austria Slovenia. Tracks are constantly being built and updated to international standards, networks are expanding, tunnels under the Alps are actively being built. In 2015, funding was approved by the European Union for the construction of a high-speed Turin - Lyon line worth $€ 25$ billion, which will connect French and Italian lines and provide a junction with Slovenia [9].

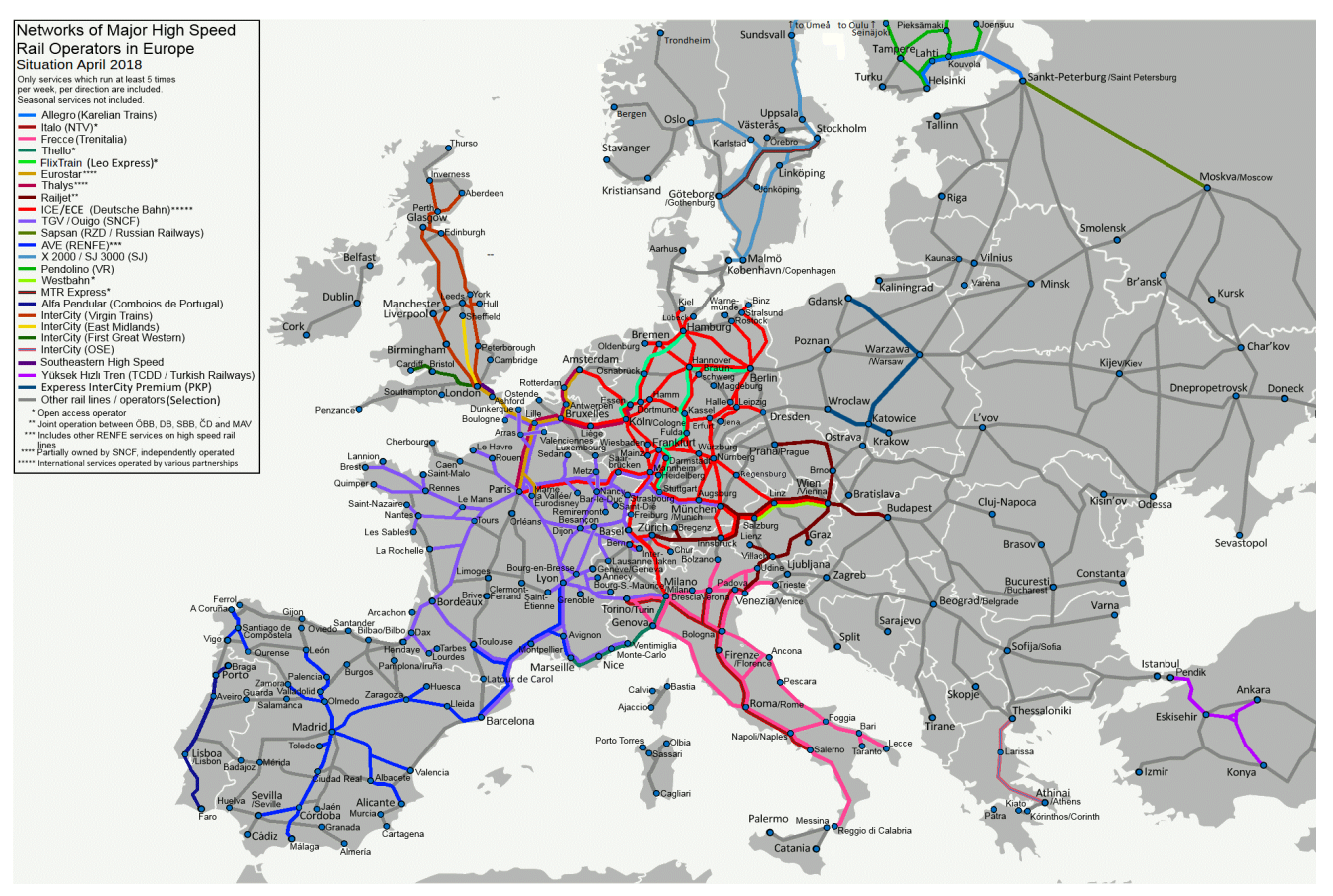

Fig. 1. High-speed rail network in Europe [10].

In 2007, a consortium of European railway operators, Railteam, was created to coordinate and promote cross-border high-speed rail transport.

The United States, during the Second World War, went its own way of developing highspeed trains reaching speeds of $124 \mathrm{~km} / \mathrm{h}$, and in 1934 - already $185 \mathrm{~km} / \mathrm{h}$. In 1935, the Hiawatha service already used trains that could reach $160 \mathrm{~km} / \mathrm{h}$.

Currently, there is not a single high-speed line in the United States, and construction is not ongoing, with the exception of California Acela Express between New York and 
Washington with a speed of $240 \mathrm{~km} / \mathrm{h}$ on limited sections of the route, but the average speed is only about $105 \mathrm{~km} / \mathrm{h}$. California plans to complete the first phase of the HSR system (San Francisco - Los Angeles - Anaheim) in 2029. Texas is studying the possibility of building a "bullet train" between Dallas and Houston. In Florida, the Brightline between Miami and Orlando has an average speed of only $130 \mathrm{~km} / \mathrm{h}$, and there are plans to increase rolling stock speeds.

After the Second World War, Japan faced a number of global problems: a high population and, in turn, congestion in roads and railways. One of the solutions to these problems was the creation of high-speed lines, and the Japanese government began a deployment program. The first Japanese narrow gauge railways reached a maximum speed of $145 \mathrm{~km} / \mathrm{h}$, which gave impetus to high-speed trains of a standard gauge, they could already reach a speed of $250 \mathrm{~km} / \mathrm{h}$. The first modern high-speed line between Tokyo and Osaka, Tōkōaidō Shinkansen or the "bullet train", was opened in 1964. The trains initially had 12 cars, 16 double-decker ones appeared later. In 1976, these trains carried their billionth passenger. Today, Japan has a network of nine high-speed rail lines connecting 22 major cities. It is the busiest high-speed rail in the world, carrying over 420,000 passengers on a regular working day. Trains travel at speeds up to $320 \mathrm{~km} / \mathrm{h}$. For more than 50 years of operation of the high-speed line in Japan, there has not been a single fatality or injured person in an accident [11].

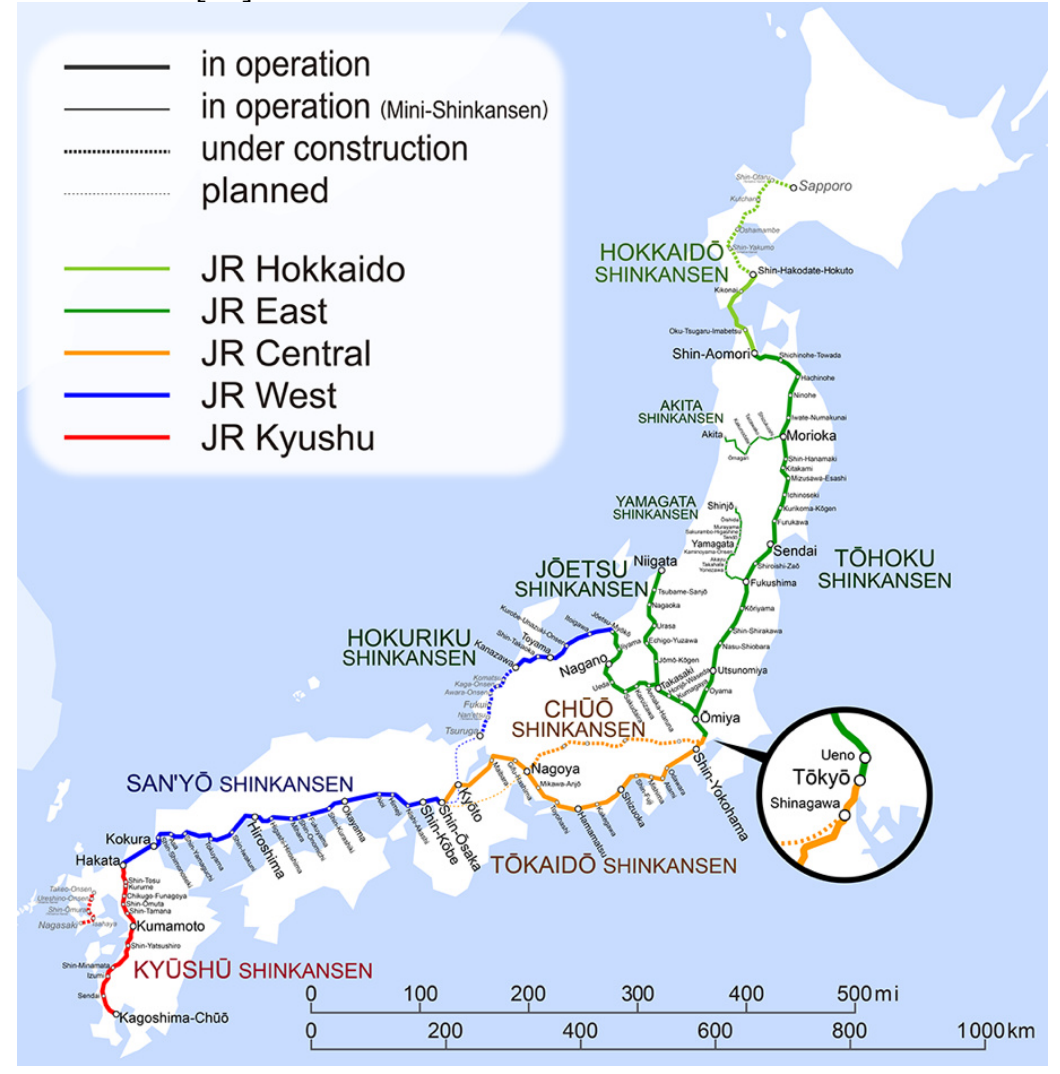

Fig. 2. HSR in Japan [12].

China began planning the current high-speed rail network in the early 1990s. The railway has been developed over the past years, because the government provided full and comprehensive support. Built according to the Japanese Shinkansen system, the service began functioning in 2008, reaching speeds from 250 to $350 \mathrm{~km} / \mathrm{h}$ from Beijing to Tianjin 
(117 km). By 2025, the Chinese railway network will stretch over 38,000 km, and 45,000 $\mathrm{km}$ in the long run. This is significantly more than all high-speed railways around the world. China initially attracted other countries to create its systems, such as Japan, Germany, France and others. And in recent years, having tremendously developed its domestic production capacities, it has won tenders for the development and construction of high-speed lines around the world [13-16].

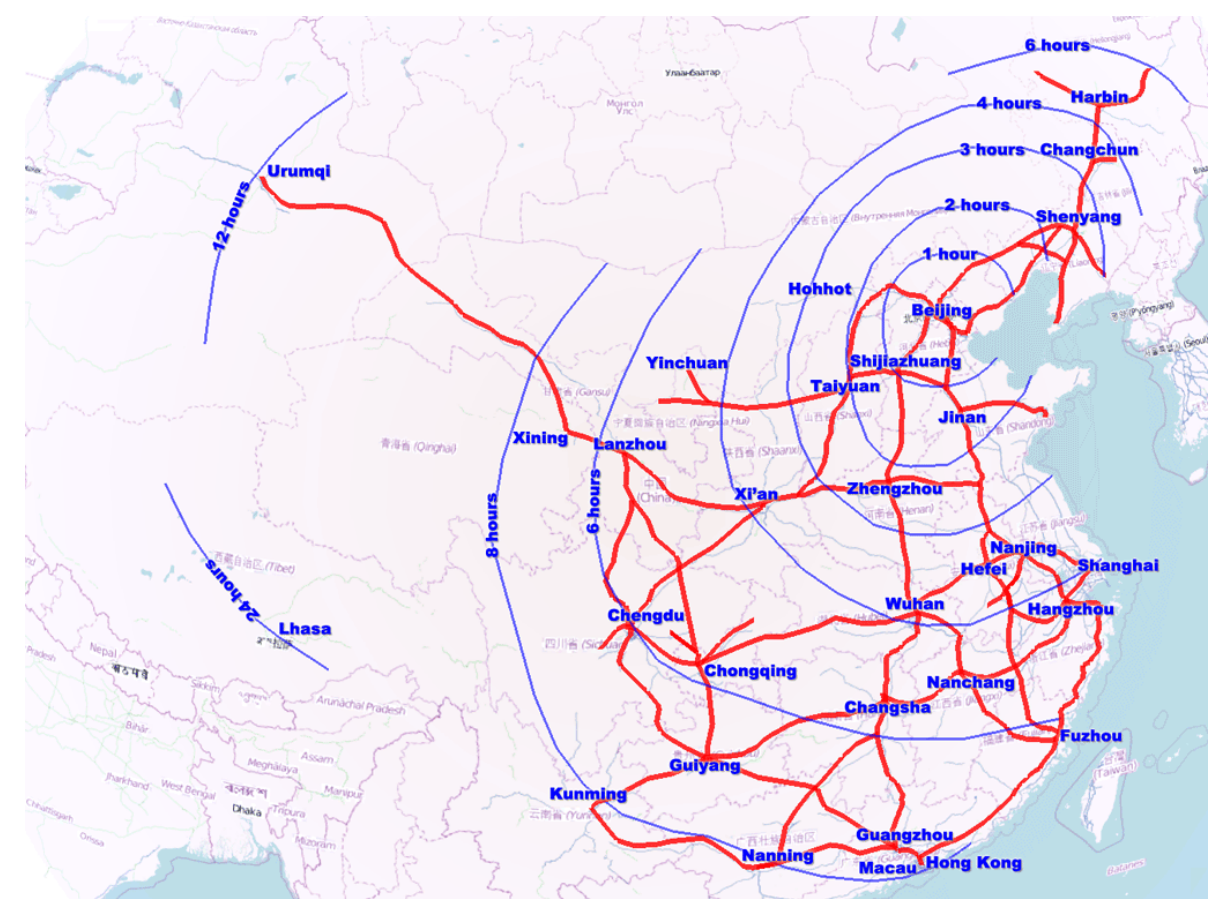

Fig. 3. HSR in China [17].

Most of China's newly built lines are designed for passenger traffic. High-speed trains can reach speeds of 300-350 km/h. On mixed-use lines (cargo-passenger), passenger trains can reach a maximum speed of $200-250 \mathrm{~km} / \mathrm{h}$. Beijing-Shanghai is China's most profitable high-speed rail with a net operating profit of more than $\$ 1$ billion (2015). The construction of this railway, with a length of $1318 \mathrm{~km}$, began in 2008, and in 2011 it was opened for commercial service. China's high-speed rail is currently carrying twice as many passengers as its domestic airlines.

In Russia, the development of high-speed and express lines began with the launch of Sapsan trains between Moscow and St. Petersburg in 2009. Over these years, they transported more than 16 million people, and the demand for high speed travel remains unsatisfied. Acceleration of economic growth and improving the quality of life of the population of Russia require, in turn, to ensure optimal speeds, comfort and cost. The HSR development program has been created, which consists of three stages: the first stage, 2015-2020 (HSR Moscow - Kazan HSR Moscow - Tula (as stage 1 of the HSR-3 MoscowAdler), ER Tula - Oryol - Belgorod (modernization of the existing infrastructure), HSR Yekaterinburg - Chelyabinsk, ER Yekaterinburg - Nizhny Tagil (modernization of the existing infrastructure)), second stage, 2020 -2025 (HSR Kazan - Elabuga, HSR Tula Voronezh, ER Moscow - Yaroslavl (construction of new sections and modernization of existing infrastructure), ER Yekaterinburg - Tyumen, ER Novosibirsk - Kemerovo, Yurga - 
Tomsk and Kemerovo - Novokuznetsk (construction of new sections and modernization of existing infrastructure)), third stage, 2025 - 2030 (HSR Elabuga - Yekaterinburg, HSR Voronezh - Rostov-on-Don, HSR-2 Cheboksary - Samara, ER Yekaterinburg - Tyumen, ER Sevastopol - Black Sea resorts) [18-25].

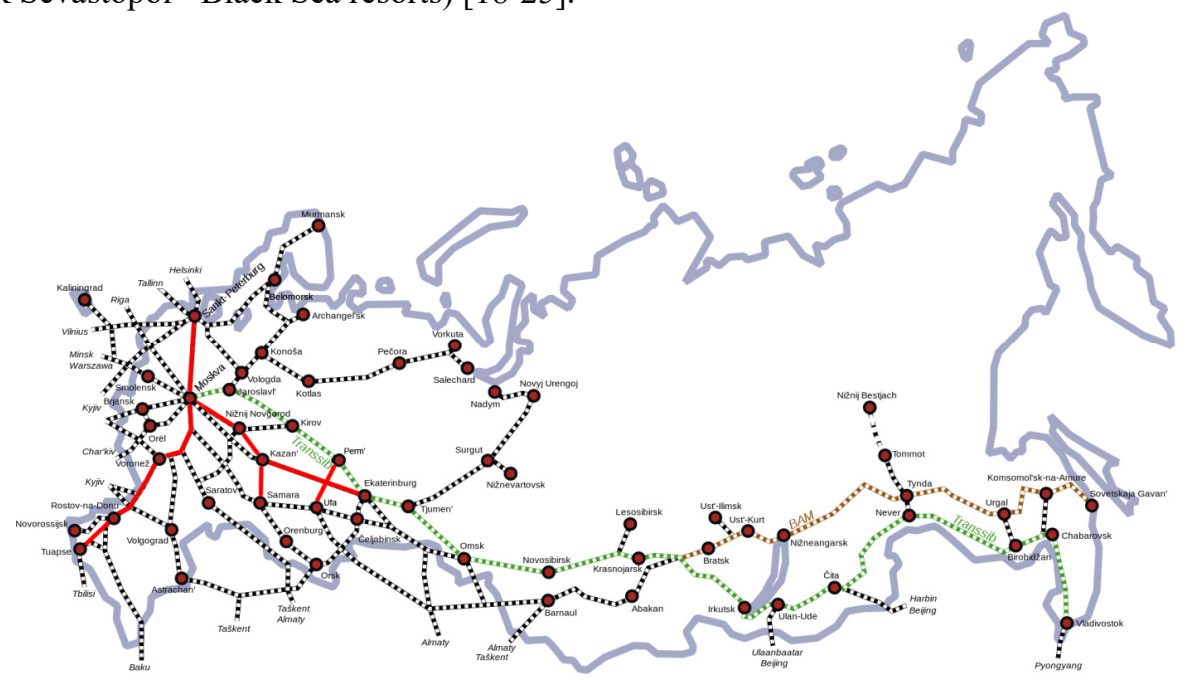

Fig. 4. HSR development program in Russia [26].

"The implementation of high-speed and express traffic projects will make a significant contribution to eliminating the bottlenecks in the Russian transport system by switching part of the passenger traffic in the long-distance traffic from existing to high-speed lines. Such a transfer will free busy lines for the transport of goods. In addition, this will remove a number of restrictions on economic growth by increasing budget revenues and gross regional product, developing engineering, tourism and other sectors of the economy" [27].

\section{Results and Discussion}

There is a sufficient amount of research in the field of assessment and determination of criteria for high-speed rail lines, for example, Steer, Davies Gleave. 2004[28], UIC. 2005[29], Venables, A.J. 2007[30],

[31]Vickerman, R. 1995, [32]Vickerman, R. 1997, [33]Vickerman, R. 2006. Such problems were discussed here: Commission for Integrated Transport, High Speed Rail's leading asset for customers and society, Evaluating urban transport improvements, the regional impacts of Trans-European networks, High-speed rail in Europe: Experience and issues for future development, Indirect and wider economic benefits of high speed rail and ect.

Thus, summing up the results of the analysis in the field of historical prerequisites for the formation of quality criteria in the development of high-speed rail lines, we can draw the following conclusions.

Germany began using its Inter-City Express (ICE) speed trains in 1991, and in 1994, Eurostar began to operate, connecting Paris to London via a tunnel. Due to the fast pace of development of high-speed trains in France, most of the other high-speed lines in Europe were created in accordance with French standards, the only exception was Germany, it has its own railway standards. 
The discrepancy between the pace of scientific and technological progress in America and the development opportunities for high-speed rail lines is identified in connection with certain criteria, such as:

- low population density in US cities creates a less dense traffic flow and makes this type of transport economically impractical;

- strong US ownership makes it difficult to use land for civilian public purposes;

- America has highly developed automobile infrastructure with huge marketing infusions into this type of transport, hence there are difficulties in switching to public transport.

- US railways are mainly owned by freight companies, which forces carriers to prefer freight trains;

- long distances between US cities are much more convenient to be served by airlines

- the political impact of some wealthy entrepreneurs who are interested in suppressing interest in the railways to maximize the use of fossil fuels.

In Japan, one of the solutions to the problems of developing high-speed lines was the creation of high-speed rail lines, and the Japanese government began a program for their further development and support.

The criteria for the prospect of building high-speed rail lines in conditions of low paying capacity of the Chinese population are as follows:

- providing a fast, reliable and convenient way to transport a large number of travelers across a densely populated country over long distances and increasing long-term economic productivity and competitiveness by connecting labor markets and freeing old railways for cargo transportation.

- in the short term, stimulating the economy by creating jobs in construction and promoting the growth of demand for building materials;

- economic integration of cities, contributing to the growth of small towns, connecting them with megacities;

- supporting energy independence and environmental friendliness - electric trains are more energy-intensive in comparison with airplanes and cars, and it is possible to use various energy sources, including renewable ones;

- promoting the development and competitiveness of Chinese manufacturers of railway equipment and technology.

As for Russia, the problem of creating high-speed rail lines today is one of the most promising industries and fields of activity. Implementation of high-speed railway projects will create the basis for dynamic economic growth. Such projects, along with their own effectiveness, act as a catalyst for the development of industries, small and medium-sized businesses, and regional development.

Thus, the authors believe that:

1. The project for the development of a high-speed rail line should be considered as an investment project with an assessment of its payback.

2. To analyze the prospects for the development of high-speed rail lines, it is possible to use methods of mathematical modeling of passenger flows with reference to the main socio-economic indicators, such as population, passenger flow, tourist flow, cargo flow.

3. The quality criteria of high-speed rail lines should be analyzed in such areas as: economic, safety, environmental, compliance with legislative standards.

4. The development of a high-speed rail network in a specific region should be integrated with urban transport networks in TEN-T.

5. It is necessary to analyze and remove technical barriers when creating a single highspeed rail network. 


\section{Conclusions}

Thus, having considered the problem of forming quality criteria in the field of development of high-speed lines, it should be noted that certain requirements have historically been formed in each region. For example, in many countries, the prerequisites for establishing requirements for quality, safety, environmental friendliness, and reliability are regulated by the regulatory field, relevant regulations, norms, standards. All this allows clearly establishing and monitoring the implementation of the requirements and conditions of activity in this important and, at the same time, very dangerous area associated with many risks.

The authors see the areas of further studies in the field of quality criteria for highspeed rail lines in the development of research in the field of determining the relationship between the concepts of quality and efficiency, the development of a scale of quality levels of high-speed rail lines as a system, and the formation of a system of indicators and performance criteria of high-speed rail lines as a system.

This paper was financially supported by the Ministry of Education and Science of the Russian Federation on the programm to improve the competitiveness of Peter the Great St.Petersburg Polytechnic University (SPbPU) among the world's leading research and education centres in the 2016-2020.

The paper was prepared with the financial support of the Russian Foundation for Basic Research in the framework of research under the project of the RFBR No. 19-010-00968.

\section{References}

1. DIRECTIVE, 96/48/ECAPPENDIX $1 / /$ http://www.uic.org/spip.php?article971

2. Guidelines for successful Public-Private Partnerships.

// http://ec.europa.eu/regional_policy/sources/docgener/guides/ppp_en.pdf

3. High-speed rail lines of Europe. http://www.eng.hsrail.ru/abouthsr/networksofhsr/europe/

4. International Union of Railways. The worldwide organisation of cooperation for railway companies. // http://www.uic.org

5. High-speed rail lines of Japan. https://www.wikiwand.com/pl/Shinkansen

6. High speed lines in the world. // http://www.uic.org/IMG/pdf/20170201_high_speed_lines_in_the_world.pdf

7. High-Speed Rail Strategic Plan.// http://www.fra.dot.gov/eLib/Details/L02833

8. China High-Speed Rail. On the Economic Fast Track. // https://www.morganstanley.com/views/perspectives/China_HighSpeed_Rai 1.pd $\mathrm{f}$

9. China statistical yearbook (2014)

// http://www.stats.gov.cn/tjsj/ndsj/2014/indexeh.htm

10. High-speed rail lines of Russia. http://www.hsrail.ru/info/vsmr/

11. D.V. Steer,High speed rail: International comparisons. Commission for Integrated Transport. Google Scholar, London (2004)

12. UIC, High Speed Rail's leading asset for customers and society. UIC Publications, Google Scholar, Paris (2005) 
13. A.J. Venables, Evaluating urban transport improvements. Cost-benefit analysis in the presence of agglomeration and income taxation. J. of Transp. Ec. and Policy, 41 (2), 173-188, Google Scholar (2007)

14. R. Vickerman, The regional impacts of Trans-European networks. The Ann. of Reg. Scie., 29, 237-254, CrossRef, Google Scholar (1995)

15. R. Vickerman, High-speed rail in Europe: Experience and issues for future development. The Ann. of Reg. Scie., 31, 21-38, CrossRef, Google Scholar (1997)

16. R. Vickerman, Indirect and wider economic benefits of high speed rail. Paper giv. at the 4th ann. conf. on railroad indust. Struct., compet. and invest., Google Scholar, Madrid (2006) 